\title{
Evaluation of Pigeonpea (Cajanus cajan (L.) Millsp.) Genetic Diversity Using Principal Component Analysis
}

\section{Gopi Krishnan $A^{1 *}$, Pandiyan $M^{2}$, Thilagam $P^{1}$, Veeramani $P^{1}$ and Nanthakumar $\mathbf{S}^{\mathbf{1}}$}

${ }^{1}$ Agricultural Research Station, Virinjipuram, Vellore District, Tamil Nadu, India

${ }^{2}$ Regional Research Station, Virudhachalam, Cuddallore District, TamilNadu, India

*Corresponding Author: Gopi Krishnan A, Agricultural Research Station, Virinjipuram, Vellore District, Tamil Nadu, India.
Received: December 06, 2021

Published: January 13, 2022

(C) All rights are reserved by Gopi Krishnan

A., et al.

\section{Abstract}

A collection of 32 redgram genotypes were evaluated for nine morphological and phenological characters by principal component analysis for determining pattern of genetic diversity and relationship among individuals. The largest variation was observed for seed yield per plant with coefficient of variation of 74.01\% followed by number of pods per plant (69.63), plant height (53.47) and number of branches (42.16). The least variation was observed in pod length with coefficient of variation of $10.60 \%$. Principal component analysis was used to assess the variation and relative contribution of various traits towards total variability. In this study, principal component 1 had the contribution from the traits such as days to maturity, days to $50 \%$ flowering, plant height and 100 seed weight, number of branches, number of pods per plant and seed yield per plant which accounted to $34.54 \%$ of the total variability. The principal component 2 explained $26.82 \%$ of total variability from days to $50 \%$ flowering and days to maturity. Number of branches and plant height had contributed $16.03 \%$ of total variability in principal component 3 . The principal component 4 explained $11.40 \%$ of total variability from the number of branches, number of seeds per pod, pod length, 100 seed weight and plant height. The cumulative variance of $88.80 \%$ of total variation among ten characters was explained by first four axes. Thus, the results of principal component analysis used in the study had revealed the high level of genetic variation and the traits controlling for the variation were identified. Hence, these entries can be utilized for trait improvement in breeding programs for the traits contributing for major variation. Correlation analysis revealed that number of pods per plant and plant height had significant and positive association with seed yield per plant and also exhibited significant positive inter correlation among them. Cluster analysis depicted two clusters and identified the groups of cultivars those were more closely related.

Keywords: Pigeonpea; Principal Component Analysis; Diversity

\section{Introduction}

Redgram is an important grain legume crop grown widely in the world. Globally, redgram is grown in an area of 56.16 lakh hectares with a production of 44.25 lakh tonnes and productivity of 788.1 $\mathrm{kg} / \mathrm{ha}$ [1]. India ranks first in redgram production globally with 38.8 lakh tonnes cultivated in 48.24 lakh hectares with productivity of $804 \mathrm{~kg} /$ hectare in 2020-21 [1]. India is the largest producer of redgram contributing for $75 \%$ of the global production. Even though India is the largest producer, it unable to supply domestic demand and import redgram every year. Even more cultivars are available; the production of redgram has been difficult to increase. The lower production of redgram is due to the cultivars are low genetic potential with poor harvest index, long crop duration that mature in 150 to 280 days, poor plant type, and susceptibility to biotic and abiotic stresses. Long duration redgram cultivars do not allow crop rotation with other crop in the same field in a year. Earliness of crop maturity can fit for multiple cropping system or crop 
rotation, escape stress (biotic and abiotic) at the end of the season and increasing the cropping efficiency of the farming system. There is large variation for days to $50 \%$ flowering in pigeon pea, ranging from less than 50 days to more than 160 days. Using this variation, we can develop a high yielding cultivar with early or extra early flowering genotypes. The present research was carried out to identify the genotypes for early flowering and maturity.

\section{Material and Methods}

Seeds of 32 entries of redgram were collected from ICRISAT, Hyderabad (Table 1) and the crop was grown during the rabi season 2014 at Agricultural Research Station, Virinjipuram which is situated at latitude of $125^{\prime} \mathrm{N}$ and longitude of 78E with sandy loam soil of $\mathrm{pH}$ 7.8. Each accession was raised in one row of $4 \mathrm{~m}$ length with $90 \mathrm{~cm}$ and $30 \mathrm{~cm}$ inter and intra row spacing respectively. Trait's observations were recorded on five representative plants per row. Recommended cultural practices were followed. The plants were evaluated for various phenological and morphological traits [2]. such as days to $50 \%$ flowering, days to maturity and morphological traits such as plant height (cm), no. of branches/plant, no. of pods/ plant, pod length $(\mathrm{cm})$, no. of seeds/pod, hundred seed weight (g) and seed yield per plant (g). The data were subjected to basic statistics, correlation analysis and Principal Component Analysis (PCA) using statistical software package Statistical Tool for Agricultural Research (STAR). Clustering analysis was performed using DAR win 5.0 software.

\section{Result and Discussion}

The first order statistics measures i.e., minimum, maximum, mean, standard deviation (sd) and coefficient of variation (CV) for measured traits are presented in the (Table 2). The overall mean for days to $50 \%$ flowering for the germplasm accessions was 102.30 days with minimum and maximum of 72 and 152 days respectively. The plant height ranged from $25.90 \mathrm{~cm}$ to $183.40 \mathrm{~cm}$ with mean of 74.24. Number of branches varied from 1.60 to 8.0 with a mean of 3.92. The maximum and minimum value for the number of pods per plant is 25 and 189.80 respectively with mean value of 54.20.

\begin{tabular}{|l|c|c|c|}
\hline S. No. & Cultivars & S. No. & Cultivars \\
\hline 1 & ICP7 & 17 & ICP10654 \\
\hline 2 & ICP26 & 18 & ICP11412 \\
\hline 3 & ICP28 & 19 & ICP11418 \\
\hline 4 & ICP2746 & 20 & ICP11419 \\
\hline 5 & ICP3046 & 21 & ICP11424 \\
\hline 6 & ICP6049 & 22 & ICP11432 \\
\hline 7 & ICP6128 & 23 & ICP11477 \\
\hline 8 & ICP6859 & 24 & ICP11543 \\
\hline 9 & ICP6971 & 25 & ICP11681 \\
\hline 10 & ICP6973 & 26 & ICP13991 \\
\hline 11 & ICP6974 & 27 & ICP14722 \\
\hline 12 & ICP7220 & 28 & ICP14974 \\
\hline 13 & ICP7260 & 29 & ICP15029 \\
\hline 14 & ICP7426 & 30 & ICP15597 \\
\hline 15 & ICP7803 & 31 & ICP15598 \\
\hline 16 & ICP8860 & 32 & ICP15599 \\
\hline
\end{tabular}

Table 1: Redgram germplasm collected for diversity analysis.

The mean value for pod length is $3.79 \mathrm{~cm}$ and showed minimum of $2.70 \mathrm{~cm}$ and maximum of $4.70 \mathrm{~cm}$. Number of seeds per pod showed mean value of 3.46 with minimum value of 2.20 and maximum of 4.30. 100 seed weight had recorded maximum of $11.00 \mathrm{~g}$ and lowest of $6.2 \mathrm{~g}$ with mean of $8.36 \mathrm{~g}$ in 32 collected entries. Days to maturity had observed with as early as of 120 days and as late as of 182 days after sowing with mean of 150.84 days. The seed yield per plant showed a wide range of $5.0 \mathrm{~g}$ to $53.10 \mathrm{~g}$ with a mean of $15.68 \mathrm{~g}$. The largest variation was observed for seed yield per plant with CV of 74.01 followed by number of pods per plant (69.63), plant height (53.47), number of branches (42.16), days to $50 \%$ flowering (18.24). Pod length has shown the least variation with CV of 10.60. The plant height was recorded with the highest deviation from the population mean (39.70) while other attribute traits such as number of pods per plant (37.74), days to $50 \%$ flowering (18.61), days to maturity (16.62), and seed yield per plant (11.61) also deviated considerably from the mean.

\begin{tabular}{|l|c|c|c|c|c|c|c|}
\hline Traits & Minimum & Maximum & Mean & Std Dev & CV (\%) & Skewness & Kurtosis \\
\hline DFF & 72.00 & 152.00 & 102.30 & 18.61 & 18.24 & 0.42 & 0.12 \\
\hline DM & 120.00 & 182.00 & 150.84 & 16.62 & 11.02 & -0.25 & -0.73 \\
\hline Plant height & 25.90 & 183.40 & 74.24 & 39.70 & 53.47 & 0.81 & 0.05 \\
\hline No. of Branches & 1.60 & 8.00 & 3.92 & 1.65 & 42.16 & 1.15 & 0.68 \\
\hline No. of pods per plant & 25.00 & 189.80 & 54.20 & 37.74 & 69.63 & 2.33 & 5.63 \\
\hline
\end{tabular}




\begin{tabular}{|l|c|c|c|c|c|c|c|}
\hline Pod length & 2.70 & 4.70 & 3.79 & 0.40 & 10.60 & -0.46 & 0.95 \\
\hline No. of seeds per pod & 2.20 & 4.30 & 3.46 & 0.56 & 16.33 & -0.81 & 0.21 \\
\hline 100 seed weight & 6.20 & 11.00 & 8.36 & 1.10 & 13.21 & -0.03 & 0.13 \\
\hline Seed yield per plant & 5.00 & 53.10 & 15.68 & 11.61 & 74.01 & 2.28 & 5.23 \\
\hline
\end{tabular}

Table 2: Descriptive statistics based on 32 accession of redgram.

DFF: Days to 50\% Flowering; DM: Days to Maturity; PH: Plant Height; NB: Number of Branches; NPP: Number of Pods Per Plant; PL: Pod Length, NSP: Number of Seeds Per Pod; 100 SW: 100 Seed Weight; SYP: Seed Yield Per Plant.

Study of skewness explains degree of departure from the normal distribution and provides information about nature of gene action that controls a trait. Kurtosis gives details about flatness or peakedness of a distribution and it estimates number of genes controlling a trait [3]. When the frequency distribution is asymmetrical, the distribution is known as skewed and it indicates the trait is controlled by non-additive gene action and may be influenced by environmental variables. The traits showing skewed distribution indicates mostly dominant gene action and positively skewed specify complementary gene interaction and negatively skewed denote duplicate gene interaction. Frequency distribution for different traits on 32 collected redgram accessions revealed different patterns of distribution as shown on (Figure 1). None of the traits had shown normal distribution. The traits such as days to $50 \%$ flowering, plant height, number of branches, number of pods per plant and seed yield per plant were positively skewed indicates complementary gene interaction. Negative skewness was observed for days to maturity, pod length, number of seeds per pod and 100 seed weight shows duplicate gene interaction.

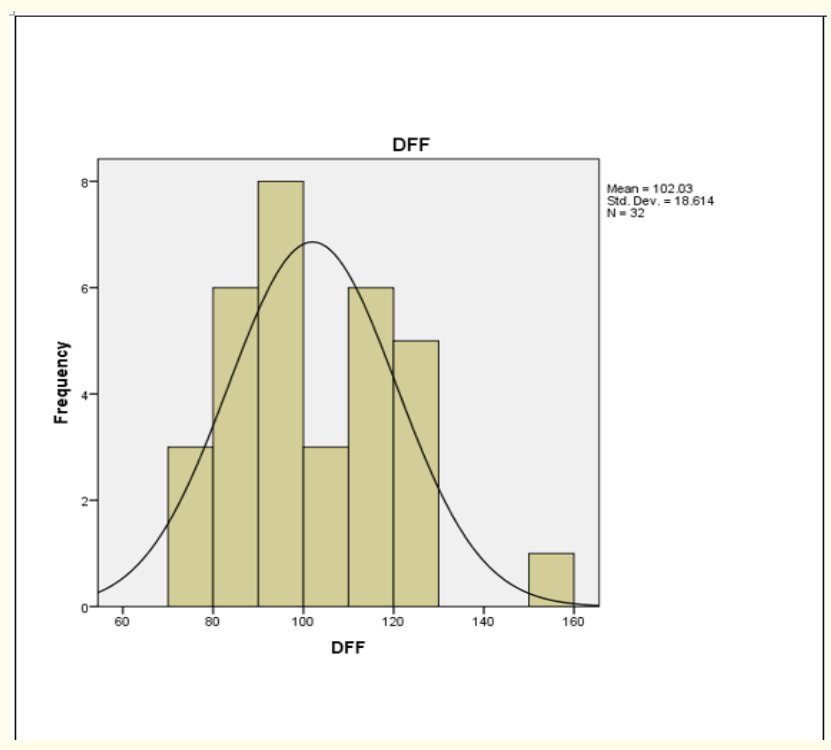

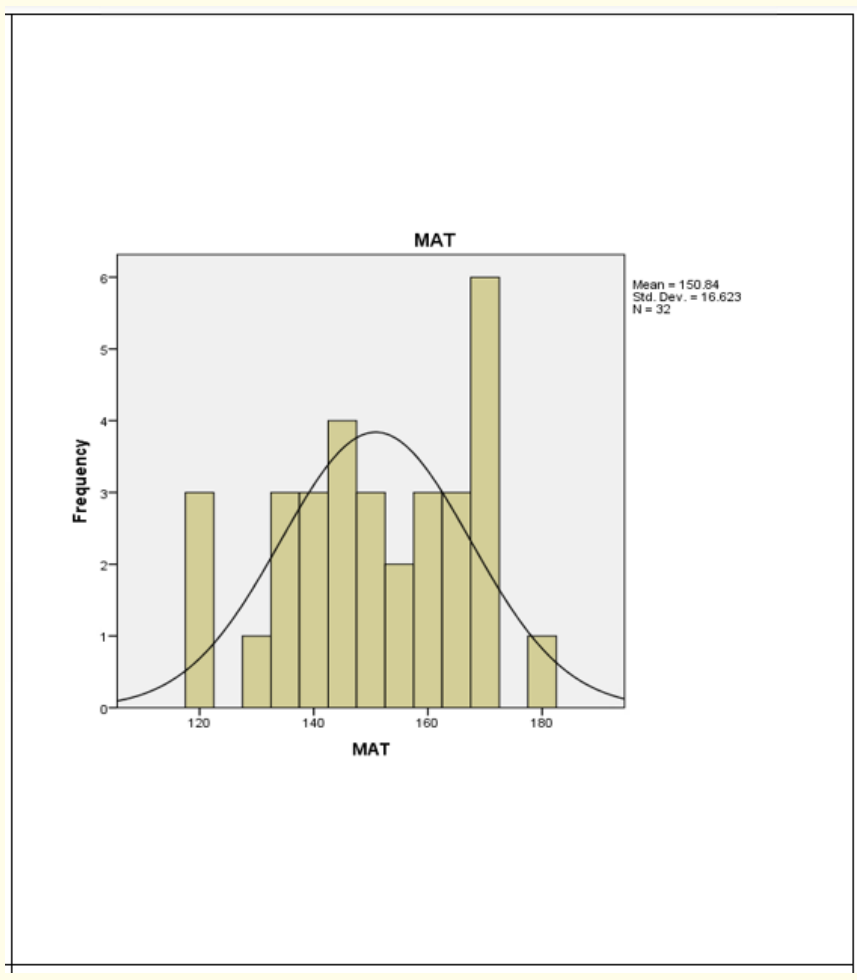



Citation: Gopi Krishnan A., et al. "Evaluation of Pigeonpea (Cajanus cajan (L.) Millsp.) Genetic Diversity Using Principal Component Analysis". Acta Scientific Agriculture 6.2 (2022): 22-30. 

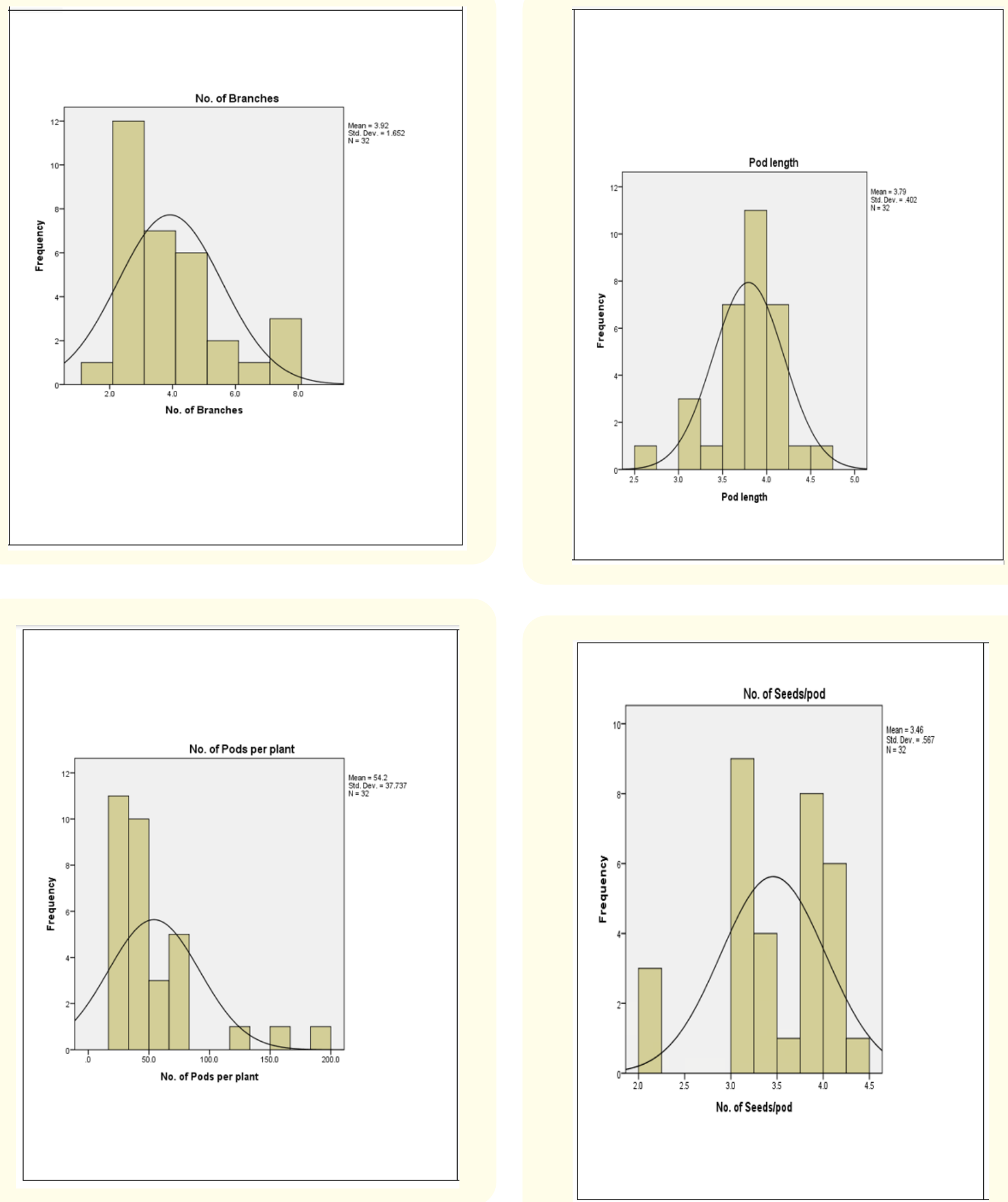




The positive values of kurtosis indicated leptokurtic curve and negative kurtosis indicated platykurtic curve. Negative kurtosis denotes absence of gene interaction while positive kurtosis indicates presence of gene interaction. The traits with leptokurtic distribution are controlled by few numbers of genes while platykurtic distributions are controlled by many numbers of genes. The traits such as days to $50 \%$ flowering, plant height, number of branches, number of pods per plant, pod length, number of seeds per pod, 100 seed weight and seed yield per plant were leptokurtic while, days to maturity were platykurtic.

\section{Principal component analysis}

Principal component analysis was used to know the genetic diversity of collected redgram entries and to measure contribution of each component to the total variance. Total variation in each principal axis was determined by number of variables. Principal component analysis measures the importance and contribution of each component to total variance. It can be used for measurement of independent impact of a particular trait to the total variance whereas

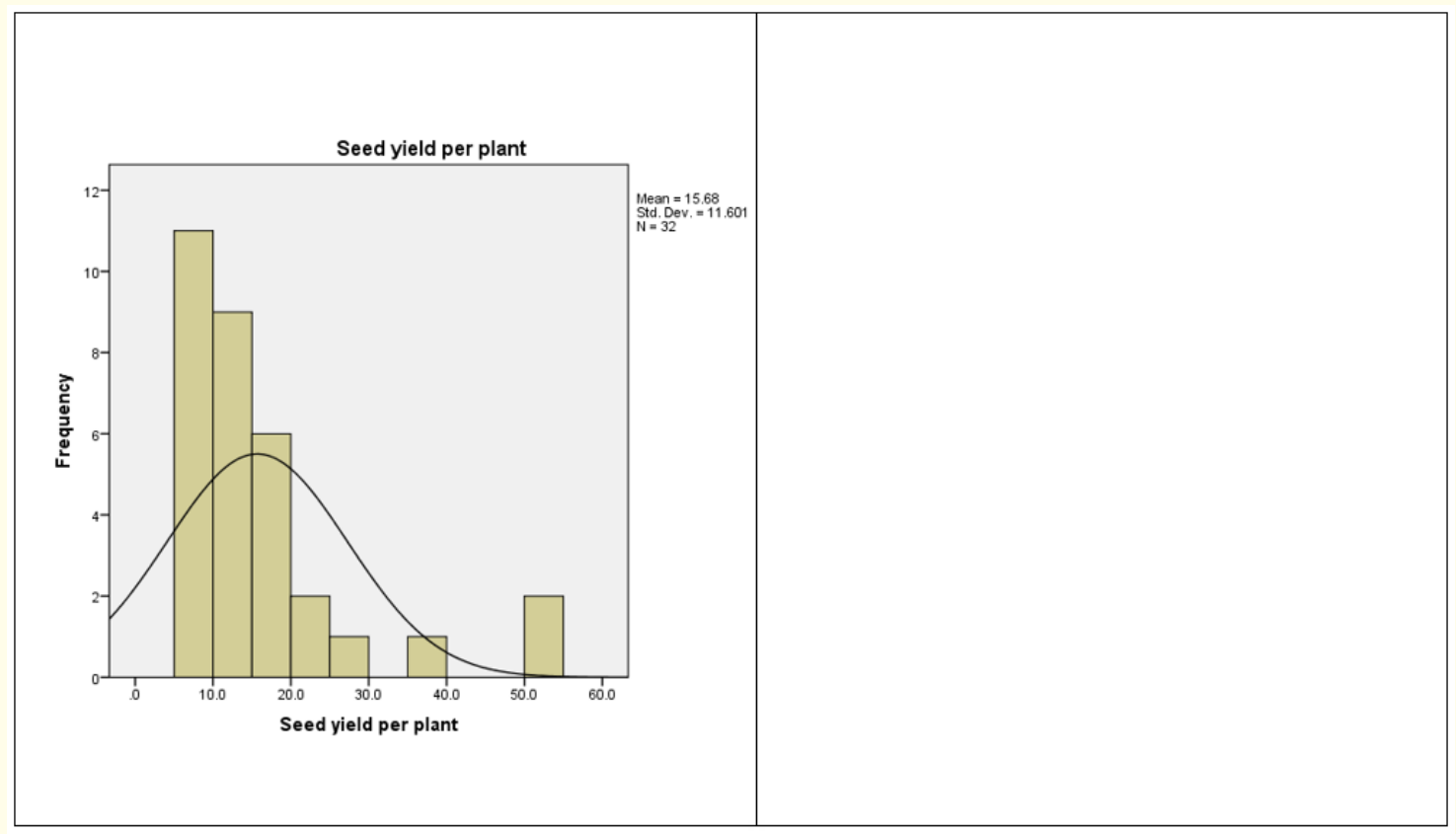

Figure 1: Frequency distribution of different quantitative traits. For trait description please see Table 1. 
each coefficient of proper vectors indicates the degree of contribution of every original variables with which each principal component is associated. The higher the coefficients, regardless of the sign, the more effective they will be in discriminating between accessions. The four principal components with cumulative variance of $88.80 \%$ was extracted which gives the clear idea of structure underlying the variables analyzed. Similar results were observed by Thanga [4].

In the current study PCA has extracted four principal components with eigen value more than 1.0 and expressed cumulative variance of $88.80 \%$ (Table 3 ). The first principal component is the largest contributor to the total variation $(34.54 \%)$ in the population followed by component two (26.82\%) component three (16.03\%) and four (11.40\%). PCA can be used to assess the independent impact of a specific trait to the total variance for each component. All the collected redgram entries were widely scattered across different quarters (Figure 2).

\begin{tabular}{|l|c|c|c|c|}
\hline $\begin{array}{l}\text { Principal } \\
\text { Components }\end{array}$ & PC1 & PC2 & PC3 & PC4 \\
\hline EigenValues & 3.11 & 2.41 & 1.44 & 1.03 \\
\hline \% of Variance & 34.54 & 26.82 & 16.03 & 11.40 \\
\hline Cumulative \% & 34.54 & 61.36 & 77.39 & 88.80 \\
\hline $\begin{array}{l}\text { Component } \\
\text { matrix }\end{array}$ & 0.44 & 0.21 & -0.40 & 0.06 \\
\hline DFF & 0.47 & 0.17 & -0.35 & 0.04 \\
\hline MAT & 0.38 & -0.33 & 0.19 & 0.26 \\
\hline Plant height & 0.15 & -0.20 & 0.50 & 0.61 \\
\hline No.of Branches & 0.08 & -0.58 & -0.07 & -0.37 \\
\hline $\begin{array}{l}\text { No of Pods per } \\
\text { plant }\end{array}$ & -0.36 & -0.23 & -0.39 & 0.38 \\
\hline Pod length & -0.38 & -0.08 & -0.42 & 0.40 \\
\hline $\begin{array}{l}\text { No.of Seeds per } \\
\text { pod }\end{array}$ & 0.05 & -0.61 & -0.18 & -0.22 \\
\hline 100 seed weight & 0.37 & -0.13 & -0.26 & 0.26 \\
\hline $\begin{array}{l}\text { Seed yield per } \\
\text { plant }\end{array}$ & & & & \\
\hline
\end{tabular}

Table 3: Eigen value and percent of total variation and component matrix for the principal components.

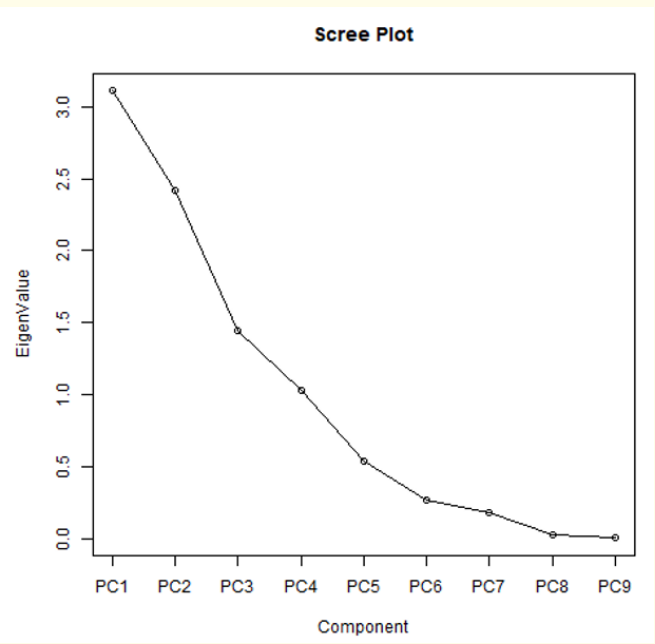

Figure 2: Scree plot depicting Eigen value variation for 9 principal components.

Principal Component 1 has $34.54 \%$ of the total variability contributed from days to $50 \%$ flowering $(0.44)$, days to maturity (0.47), plant height $(0.38)$, pod length $(-0.36)$, number of seeds per pod (-0.38), 100 seed weight (0.37).

The Principal Component 2 is related days to $50 \%$ flowering (0.21), plant height $(0.33)$, number of branches $(-0.20)$, number of pods per plant $(-0.58)$, pod length $(-0.23)$ and Seed yield per plant $(-0.61)$ that explained $26.82 \%$ of total variability.

The Principal Component 3 has $16.03 \%$ of the total variability contributed from days to $50 \%$ flowering $(-0.40)$, days to maturity $(-0.35)$, number of branches (0.50), Pod length (-0.39), Number of Seeds per pod (-0.42) and 100 seed weight $(-0.26)$.

Similarly plant height $(0.26)$, number of branches (0.61), number of pods per plant (-0.37), Pod length (0.38), Number of Seeds per pod (0.40), 100 seed weight (0.26) and Seed yield per plant $(-0.22)$ had contributed for the total variance of $11.40 \%$ from Principal Component 4. Manyasa., et al. [5] reported a cumulative variance of $76.9 \%$ of total variation among 12 characters as explained by the first five axes in a genetic diversity analysis in pigeonpea.

\section{Biplot analysis}

The biplot can be utilized to think about the associations between traits and trait outline of the genotype. The cosine of the 


\begin{tabular}{|l|c|c|c|c|}
\hline $\begin{array}{l}\text { Principal } \\
\text { Components }\end{array}$ & PC1 & PC2 & PC3 & PC4 \\
\hline EigenValues & 3.11 & 2.41 & 1.44 & 1.03 \\
\hline \% of Variance & 34.54 & 26.82 & 16.03 & 11.40 \\
\hline Cumulative \% & 34.54 & 61.36 & 77.39 & 88.80 \\
\hline Component matrix & & & & \\
\hline DFF & 0.44 & 0.21 & -0.40 & 0.06 \\
\hline MAT & 0.47 & 0.17 & -0.35 & 0.04 \\
\hline Plant height & 0.38 & -0.33 & 0.19 & 0.26 \\
\hline No.of Branches & 0.15 & -0.20 & 0.50 & 0.61 \\
\hline No of Pods per plant & 0.08 & -0.58 & -0.07 & -0.37 \\
\hline Pod length & -0.36 & -0.23 & -0.39 & 0.38 \\
\hline No.of Seeds per pod & -0.38 & -0.08 & -0.42 & 0.40 \\
\hline 100 seed weight & 0.37 & -0.13 & -0.26 & 0.26 \\
\hline Seed yield per plant & 0.05 & -0.61 & -0.18 & -0.22 \\
\hline
\end{tabular}

Table a

angle between the traits explains the correlation between the traits $[6,7]$. If the angle between the traits is less than $90^{\circ}$ indicates the positive correlation between them, if the angle is greater than $90^{\circ}$ indicates negative correlation and when angle is of $90^{\circ}$ indicates zero correlation. The biplot ordination indicated positive associations of days to $50 \%$ flowering, days to maturity, plant height and 100 seed weight having obtuse angle among them. Likewise, plant height, number of branches, number of pods per plant and seed yield per plant showed positive association and having obtuse angle among them. Days to $50 \%$ flowering and days to maturity having obtuse angle with number of pods per plant, pod length, number of seeds per pod and seed yield per plant traits indicated negative association with these traits.

The angle between a genotype and a trait indicates the relative level of genotype for the traits. Thus less than $90^{\circ}$ (acute angle) indicates that the genotype is above average for the trait; more than $90^{\circ}$ (obtuse angle) indicates that the genotype is below average for the trait; and $90^{\circ}$ (right angle) indicates that the genotype is average for the trait. A vector drawn from origin to each trait (i.e.) the length distance indicates the amount of variation for the trait $[6,8]$. Higher the length represents more variation and lower the length indicates less variation. In this study days to $50 \%$ flowering, days



Figure 3: Distribution of cultivars across two components.

to maturity, plant height, number of pods per plant and seed yield per plant were well represented with high amount of variability (Figure 3).

\section{Correlation analysis}

Number of pods per plant had highly significant and positive association with seed yield per plant and plant height had significant and positive association with seed yield per plant. Number of pods per plant and height exhibited significant positive inter correlation among themselves (Table 4). Therefore, selection of any one of the characters would simultaneously bring improvement in the associated character and finally in the yield. Days to 50\% flowering had a highly significant positive association with days to maturity revealing the considerable commonness in the expression of genes responsible for these traits. Days to $50 \%$ flowering and days to maturity had negative association with number of branches, number of pods per plant, pod length, number of seeds per pod and seed yield per plant. Pod length had highly significant positive association with number of seeds per pod.

\begin{tabular}{|l|c|c|c|c|c|c|c|c|}
\hline Traits & MAT & $\begin{array}{c}\text { Plant } \\
\text { height }\end{array}$ & $\begin{array}{c}\text { No. of } \\
\text { Branches }\end{array}$ & $\begin{array}{c}\text { No. of Pods } \\
\text { per plant }\end{array}$ & $\begin{array}{c}\text { Pod } \\
\text { length }\end{array}$ & $\begin{array}{c}\text { No. of } \\
\text { Seeds/pod }\end{array}$ & $\begin{array}{c}\text { 100 seed } \\
\text { weight }\end{array}$ & $\begin{array}{c}\text { Seed yield } \\
\text { per plant }\end{array}$ \\
\hline DFF & $.973^{* *}$ & .261 & -.101 & -.138 & -.348 & -.282 & $.472^{* *}$ & -.124 \\
\hline MAT & & .318 & -.039 & -.069 & $-.392^{*}$ & -.335 & $.488^{* *}$ & -.069 \\
\hline
\end{tabular}




\begin{tabular}{|c|c|c|c|c|c|c|}
\hline Plant height & $.552^{* *}$ & $.415^{*}$ & -.252 & -.347 & $.465^{* *}$ & $.415^{*}$ \\
\hline No. of Branches & & .081 & -.086 & -.188 & .129 & .076 \\
\hline No. of Pods per plant & & & .136 & -.074 & .136 & $.969^{* *}$ \\
\hline Pod length & & & & $.762^{* *}$ & -.115 & .301 \\
\hline No. of Seeds/pod & & & & & -.231 & .081 \\
\hline 100 seed weight & & & & & & .244 \\
\hline
\end{tabular}

Table 4: Pearson's correlation coefficients among agronomic characteristics and yield parameters of evaluated redgram accessions. *, ** Significant levels at $5 \%$ and $1 \%$ probability respectively.

The cluster analysis was done using DARwin 5 software. The dendogram drawn out of UPGMA depicted two broad clusters contains 29 genotypes in one cluster and other 3 genotypes in second cluster. Cluster analysis identified the groups of cultivars those were more closely related. Cluster A is again sub cluster into two a1 and b1of which a1 had 18 genotypes. Sub cluster b1 had 11 geno- types. Major cluster B had no sub cluster and had three genotypes ICP6973, ICP6128, ICP6974 representing high number of pods per plant. In B1 subgroup the genotypes representing the very early flowering ICP15029, ICP15599, ICP15597 and ICP15598 grouped close to each other (Figure 4). Bhavana., et al. [9] grouped the 17 genotypes of pigeon pea into two main clusters.



Figure 4: Grouping of cultivar based on clustering upon agronomic characteristics and yield parameters of evaluated redgram accessions. 


\section{Conclusion}

The present study utilized PCA to assess the genetic variation of morphological traits and yield components in redgram. The analysis identified days to $50 \%$ flowering, days to maturity, plant height, number of branches, number of pods per plant, 100 seed weight and seed yield per plant mostly contributed to the variation in different principal components. Hence, the result will be used to identify parents for improving various morphological traits analyzed in this study. The cluster analysis classified the redgram in to two clusters revealing that hybridization of redgram among distant clusters could lead to increase in heterosis. The crossing between the first major cluster pigeon pea ICP6128, ICP6973 and ICP6974 and second major cluster ICP 11681 will give high heterosis with better segregants in the $\mathrm{F}_{2}$ generation. Making crossing between high number of pods per plant genotypes ICP6128, ICP6973 and ICP6974 with early flowering genotypes ICP15029, ICP15597, ICP155988 and ICP15599 will provide better segregants for high yielding line with extra early duration.

\section{Bibliography}

1. Anonymous, Redgram Outlook Report- January to May 2021 Agriculture Market Intelligence Centre, ANGRAU, Lam (2021).

2. ICRISAT. "Descriptors for Pigeonpea [Cajanus cajan (L.) Millsp.]". International Crops Research Institute for the Semi-Arid Tropics, Patancheru, India (1993).

3. Roy D. "Plant Breeding: Analysis and Exploitation of Variation". India Narosa Publishing House (2000).

4. Hemavathy AT., et al. "Principal Component analysis in Pigeonpea (Cajanus cajan Millsp.)”. Electronic Journal of Plant Breeding 8.4 (2017): 1133-1139.

5. Manyasa EO., et al. "Variability patterns in Ugandan Pigeonpea landraces". Journal of SAT Agricultural Research (2009): 7.

6. Yan W and J Frégeau-Reid. "Genotype by Yield*Trait (GYT) Biplot: a Novel Approach for Genotype Selection based on Multiple Traits". Scientific Reports 8 (2018): 8242.

7. Sharifi PA Hossein and P Masoumeh. "Evaluation of variations in chickpea (Cicer arietinum L.) yield and yield components by multivariate technique". Annals of Agricultural Sciences 16 (2018): 136-142.

8. Rathinavel K. "Principal Component Analysis with Quantitative Traits in Extant Cotton Varieties (Gossypium hirsutum L.) and Parental Lines for Diversity". Current Agriculture Research 06.1 (2018): 54-64.
9. Bhavana P., et al. "Genetic diversity and principal component analysis for yield characters of Pigeonpea landraces of Eastern India". International Journal of Chemical Studies SP6 (2019): 547-551.

\section{Assets from publication with us}

- Prompt Acknowledgement after receiving the article

- Thorough Double blinded peer review

- Rapid Publication

- Issue of Publication Certificate

- High visibility of your Published work

Website: www.actascientific.com/

Submit Article: www.actascientific.com/submission.php

Email us: editor@actascientific.com

Contact us: +919182824667 